\title{
Meso e macro determinants of the entrepreneurial success in university spin-offs
}

\author{
Loredana Lucci ${ }^{1}$
}

\begin{abstract}
The study purposes to investigate the determinants of entrepreneurial success in university spin-offs (USOs) in Italy using a two- level of analysis: the meso level and the macro level. Using the Resource-Based View theory Th and the Knowledge Spillover Theory of Entrepreneurship, a framework to estimate the impact of the two contextual level has been explored. The results from the empirical analysis of sample of 405 Italian USOs, the results shows that USOs' success is related with the resources of the parent university (meso level) and regional area (macro level) targeted to support the spillover process and the related technology transfer to the market.
\end{abstract}

JEL classification numbers: O30, O32.

Keywords: University spin-offs, Meso level, Macro level, University, Region, Italy.

${ }^{1}$ University of Teramo, via R. Balzarini n. 1., 64100. Teramo, Italy.

Article Info: Received: November 3, 2021. Revised: November 17, 2021.

Published online: November 25, 2021. 


\section{Introduction}

In the last years, the attention exposed by scholars in the growth factors and promoting tools of university entrepreneurship through University spin-offs (USOs) has improved (Fini et al., 2021; Sciarelli et al., 2021; Baldini, 2010; Sternberg, 2014; Pazos et al., 2012). These university start-ups, in fact, are an active instrument in inspiring the formation and growth of knowledge-based economies (Benneworth and Charles 2005; Sternberg, 2014). The determinants linked with their formation and development have become strategic matters in the policy actions regarding the dissemination and promotion of innovation in specific environmental contexts (Lockett et al. 2005).

Nevertheless, the USOs, combining the features of small and technologyknowledge based firms (Shane, 2004; Fini et al., 2021), face the typical difficulties linked to the start of a new corporate and the efforts in emerging and commercializing the technologies developed from the parent organization (Sciarelli et al., 2021). Literature has been claimed (Hall, Rosenberg, 2010; Stoneman, 1995) that USOs are very sensitive to several kinds of market failures, particularly throughout the early stage; therefore, becoming crucial the financing issues in the fostering support of USOs development (Prokop et al., 2019). In this view, the parent universities frequently can fund only the expenditures associated to legal protections of the technology-knowledge to spin-out, in line with their intellectual property policy. However, only few parent organizations have enough financial resources to support the technological and commercial processes involving the young spin-off firm (Ndonzuau et al., 2002). In this constrained context, a relevant role in the financing of USOs is played by external actors of the entrepreneurial environment, as private financial capital, taking the form of friends and family, business angels and venture capitalists: these agents are most important in the fragile path of development of this type of firm (Lockett and Wright, 2005); especially during the post-incorporation stage (Lockett et al., 2005). In view of these considerations, the financing gap is clearly one of the most issues in the effective development of entrepreneurial efforts of the university start-ups (Oakey, 2003).

In accordance with the theoretical framework used by these previous researches, spin-offs might diverge meaningfully on the basis of the resources and competences held, strictly associated to the context of university affiliation that can enable their growth throughout several backing tools (Rasmussen and Borch, 2010; Rasmussen, Mosey and Wright, 2014) and the characters, the structure and the relations with the environmental region (Fini et al., 2021; Sternberg, 2014; Kolympiris et al., 2014). The theoretical approach proposed here can be completed by the assumptions contained in the Knowledge Spillover Theory of Entrepreneurship applied to the regional context (Audretsch and Lehmann, 2005), which offers a focus on the creation of entrepreneurial chances arising from knowledge investments by incumbent firms and public research organizations that are not totally appropriated by those incumbent enterprises (Acs et al., 2013) and helps us 
to understand how the amount invested in knowledge by universities and regions is linked to the development of entrepreneurial activity arising from each university (Audretsch and Lehmann, 2005).

\section{Theoretical background}

The influencing determinants of USOs are several and diverse. Literature usually separates such determinants into macro, meso and micro (Djokovic and Souitaris, 2008), which can merge into various types of resources required for the company development (Pazos et, 2012). The paper investigates the macro and meso aspects, in order to identify the characteristics of the areas to compare, by following the theoretical and methodological approach of the resource-based view theory, the dynamic capabilities concepts and the Knowledge Spillover theory of Entrepreneurship.

\subsection{Meso factors}

Previous studies (Powers and McDougall, 2005; Shane, 2004) have investigated the relationship between contextual factors and the generation of USOs. The university milieu is one of the key contextual elements, diversely connected to the growth of university spin-offs (Fini et al., 2011; Rasmussen and Borch, 2010). First, a key role is performed by the inventions patented by the academic institution to be transferred to the market (Shane, 2004). Technology prominence and scientific outcomes attained by universities can be a critical input to the establishment of spin-off processes, generating a source of entrepreneurial opportunities by encoding the knowledge produced (Van Looy et al., 2011). Secondly, university policies relating to technology transfer models adopted can significantly affect the process of generation and development of USOs (Perkmann et al., 2013; Shane, 2004). In this regard, the active participation of university in the shareholding configuration of the USOs is a valued backing tool decreasing their capital requirements and increasing their liquidity (Di Gregorio and Shane, 2003). An influential element in the growth of academic entrepreneurship is the amount of R\&D funding obtained by university, as evidenced by several studies (Van Looy et al., 2011). Similarly, the level of human resources employed in that activity is a key factor in the development of new technologies and ideas to spin out new ventures (Vinig and Van Rijsbergen, 2010). The development of USOs is also determined by the infrastructural support provided by business incubators and science parks in the technology transfer processes (Al-Mubaraki and Busler, 2011). Indeed, several authors argue that business incubators and scientific parks activate these processes, linking university to industry, assisting the founders by providing support in both managerial especially marketing, which is crucial for their success - and infrastructural terms (O'Shea et al., 2008). 


\subsection{Macro factors}

It has been observed (Fini et al., 2011; Kolympiris et al., 2014) that the features of the local context can create a support network which is likely to produce positive effects on the USOs development. Indeed, the genesis and success of the spin-out processes are very closely related to the presence of external resources (Gilbert et al., 2008), which may occur in an area where specific factors have developed, as well as to the way in which these are interconnected (Colombo and Piva, 2005). In this sense, the role of the industrial context in terms of positive externalities and spillovers is crucial (O'Shea et al., 2007), along with the presence of regional entrepreneurial networks and technological clusters (Sorenson and Audia, 2000), which may have a significant effect on the purposes of academic founders to start the spin-off company, as well as gain access to social capital (Audretsch and Keilbach, 2004). At these enabler elements of academic entrepreneurship is added the amount of innovation created in a socio-economic context (Smith et al., 2014; Sternberg, 2014), chiefly measured by the regional expenditure on R\&D (Fini et al, 2011). The outcomes achieved from this kind of asset have been observed to be a confident and indirect result of mid-term impacts on new technology ventures. These financial resources can be both private and public, since governments are likely to encourage and support new high-tech start-ups due to non-optimal investment in new technologies resulting from the high costs and risk relating to the innovation diffusion processes to the market (Vendrell-Herrero et al., 2010). Previous studies (e.g. Tödtling et al., 2011) investigated the processes related to open innovation, i.e. those innovative processes developed and disseminated in regional knowledge. According to this approach, the collaboration among local businesses and universities can contribute to create a supportive environment to the full development of spin-off projects through academic research and development, consultancy and contract research (O 'Shea et al, 2005). This network facilitates the pursuit of open knowledge paths for a rapid development of the young university start-ups (Hayter et al., 2018; Fini et al., 2011).

\section{Method}

\subsection{Sample and data}

It was analysed a sample of USOs extracted from Netval database (www.netval.it) on 31 December 2020 (database collecting the population of research spin-off existing in Italy). In detail, from the 747 USOs identified were excluded inactive ones (34), those in liquidation and deleted (193), along with those firms for which no comparable data were available (115). Ultimately, it was analysed a sample of 405 active USOs, accounting for $54.21 \%$ of the population identified. The collection of secondary data was performed with reference to the financial information of USOs sampled, resulting from the analysis of financial statements and further company documents extracted from Infocamere database and Aida BdV database (containing financial, biographical and merchandise data of about 700,000 Italian active companies). 
Table 1 summarizes the domains and variables used in our study and provides detailed information on their characterization and source.

Table 1: Definition of variables

\begin{tabular}{|c|c|c|}
\hline Class & Variable & Description \\
\hline Dependent variable & AssetLN_ASO & $\begin{array}{c}\text { Natural log of total assets for university } \\
\text { spin-off i }\end{array}$ \\
\hline $\begin{array}{c}\text { University-level } \\
\text { success variables }\end{array}$ & Uni_R\&Dexp & $\begin{array}{c}\text { Intramural expenditures in R\&D of the } \\
\text { University (thousands of Euros) }\end{array}$ \\
\hline & Uni_R\&DStaff & $\begin{array}{c}\text { Personnel in research and development } \\
\text { (R\&D) activities of the University - } \\
\text { (full time equivalent) }\end{array}$ \\
\hline & \%Uni_sharecapital & $\begin{array}{c}\text { Percentage share of universities in the } \\
\text { university spin-off i }\end{array}$ \\
\hline Local context-level & NBank_incub & $\begin{array}{c}\text { Number of incubators affiliated with } \\
\text { financialinstitutions }\end{array}$ \\
\hline & NPublic_incub & Number of public-funded incubators \\
\hline & CompEntrep_index & $\begin{array}{c}\text { Indicator of the degree of } \\
\text { competitiveness and entrepreneurial } \\
\text { vivacity in theregion }\end{array}$ \\
\hline & Innovation_index & $\begin{array}{c}\text { Indicator of the degree of } \\
\text { innovativeness in the region }\end{array}$ \\
\hline & Public_R\&Dexp & $\begin{array}{c}\text { Total of R\&D expenditure in the } \\
\text { government sector }\end{array}$ \\
\hline LocalR\&D_staff & $\begin{array}{c}\text { Total of R\&D personnel and } \\
\text { researchers in the region }\end{array}$ \\
\hline
\end{tabular}

\subsection{Analytical approach}

The investigation of the effects of contextual dynamics on USOs was performed into two phases. In the first phase were carried out descriptive statistics computed for the entire sampled; while, in the second phase, it was developed a linear regression model. 
Table 2: Descriptive statistics

\begin{tabular}{|c|c|c|c|c|c|}
\hline & Mean & Standard Deviation & Variance & Min. & Max. \\
\hline \multicolumn{6}{|c|}{ Dependent variable } \\
\hline AssetLN_ASO & 11.7708 & 1.3710 & 1.8796 & 8.6721 & 16.2451 \\
\hline \multicolumn{6}{|c|}{ University-level success variables } \\
\hline NUnincub & 7.3432 & 3.2040 & 10.2656 & 1.0000 & 14.0000 \\
\hline \%Uni_sharecapital & 3.9033 & 6.8247 & 46.5763 & 0.0000 & 100.0000 \\
\hline Uni_R\&DStaff & 5469.7705 & 3431.7015 & 11776575.3566 & 948.2000 & 12337.3000 \\
\hline Uni_R\&Dexp & 399479.8878 & 225208.1752 & 50718722160.7142 & 89855.9787 & 779350.4456 \\
\hline \multicolumn{6}{|c|}{ Local context-level success variables } \\
\hline CompEntrep_index & 1377999021.6811 & 4350918018.4131 & 18930487602951900000.0000 & -209665.0000 & 15082622814.0000 \\
\hline Innovation_index & 417017819.2784 & 2205927986.5049 & 4866118281645470000.0000 & -277116.0000 & 12060392082.0000 \\
\hline Public_R\&Dexp & 346.8390 & 147.1626 & 21656.8437 & 75.0000 & 828.5000 \\
\hline LocalR\&D_staff & 1.4131 & 0.4002 & 0.1601 & 0.4600 & 3.0200 \\
\hline NPublic_incub & 9.1605 & 5.0268 & 25.2687 & 0.0000 & 18.0000 \\
\hline NBank_incub & 2.7531 & 2.2882 & 5.2359 & 0.0000 & 7.0000 \\
\hline
\end{tabular}




\section{Results}

\subsection{Descriptive statistics}

Table 2 shows the descriptive statistics involving the USOs performance variables, university-level success variables and local context-level success variables. Based on the 405 USOs explored in our study, the results show how the amplitude of the asset value of USOs measured by the natural logarithm of total assets indicates an average of 11.7708 with a variance in the sample of 1.8796 and a standard deviation of 1.3710 , revealing a low dispersion in this type of success variable.

As far as the university-level variables are concerned, it is worthwhile noting that the values assumed for each firm sampled present a moderate dispersion, especially for the "Uni_R\&Dexp" and "Uni_R\&DStaff", thus underlying the pronounced differentiation in the basic resources and fostering mechanisms of the academic entrepreneurship between universities. Similar remarks can be made for local context-level variables, for the variables labeled "CompEntrep_index" and "Innovation_index"; nevertheless, the variable "LocalR\&D_staff" shows a low sample variance, lower than 1 (as the standard deviation: 0.4002), becoming the variable less dispersed in the whole set used for the analysis. 


\subsection{Estimation of the defined regression models}

Table 3 shows the results of the multiple linear regression analysis related to the estimation of our model. In detail, it can be noted how the standardized coefficients of the variable "Uni_R\&Dexp" are statistically significant in the expected directions (we considered valid only estimations with a significance level under the $10 \%$ ); thus, the estimated coefficients imply that the expected performance of USOs increases by $13.6 \%$, if the amount of university- funded research increases by $1 \%$, all other things being equal.

The results of the regression coefficients for the remaining university-level variables in the estimated model are not statistically significant; in addition, the "NUnincub" is negative in relation to the USOperformance.

As regards the estimation of coefficients related to the local context-level variables, the results shown do not always have the expected directions and an acceptable statistical significance. More specifically, the prominence of the research resources available in the local context seems to stimulate the development of USO activities, as the variable "Public_R\&Dexp" shows positive and statistically significant relationships with the dependent variables.

Nevertheless, the coefficient estimation concerning the relation with the variable "Innovation_index" is statistically significant, but it is not in the expected direction, and that's why the macro factors related to the innovation prominence of local contexts do not seem to have an effective impact on USOs; on the contrary, these same factors seem to hinder the success of USOs.

Table 3: Model estimation

\begin{tabular}{|c|c|c|c|c|c|}
\hline & \multicolumn{2}{|c|}{ No Standardized Coefficients } & $\begin{array}{c}\text { Std. } \\
\text { Coefficients }\end{array}$ & & \\
\hline & B & $\begin{array}{c}\text { Standard } \\
\text { Deviation Error }\end{array}$ & Beta & t & Sig. \\
\hline (Costant) & 11.129 & 0.287 & & 38.716 & 0.000 \\
\hline Nunincub & -0.011 & 0.031 & -0.025 & -0.355 & 0.723 \\
\hline \%Uni_sharecapital & 0.010 & 0.010 & 0.048 & 0.937 & 0.349 \\
\hline Uni_R\&Dexp & $8.281 \mathrm{E}-07$ & 0.000 & 0.136 & 1.661 & 0.097 \\
\hline CompEntrep_index & $1.334 \mathrm{E}-11$ & 0.000 & 0.042 & 0.692 & 0.490 \\
\hline Innovation_index & $-8.045 \mathrm{E}-11$ & 0.000 & -0.129 & -2.442 & 0.015 \\
\hline Public_R\&Dexp & 0.001 & 0.001 & 0.122 & 1.966 & 0.050 \\
\hline NBank_incub & -0.009 & 0.056 & -0.016 & -0.169 & 0.866 \\
\hline
\end{tabular}

\section{Conclusion}

The study aimed to explore the joint effect of university and local context-level determinants on the USO success in terms of total assets performance. The multilevel analyses allowed us to measure in a more comprehensive and integrated way the USO patterns of development; while, at the same time, the interactions 
between fostering mechanisms and factors at various contextual levels turned out to be an optimal method to assess the partial effects of determining factors of the academic entrepreneurship growing perspectives.

The empirical analysis pointed out how these facilitating, and promoter factors of USOs do not seem to explain in a significant extent the success and development of spin-out processes in the Italian context.

In conclusion, through the empirical analysis of the joint points of observation university and local context levels - and based on previously tested theoretical approaches and some new investigation elements (related to the theoretical models of reference), this paper could represent a contribute to the current debate on the effects and effectiveness of fostering mechanisms and key features of universities and local context in evaluating the patterns of success and development of USOs; and, particularly, it could encourage the empirical research on the direct and indirect effects of contextual factors on the internal - specific - USO performance.

\section{References}

[1] Acs, Z. J., Audretsch, D. B. and Lehmann, E.E. (2013). "The knowledge spillover theory of entrepreneurship", Small business economics, vol. 41, no. 4, 2013, pp. 757-774.

[2] Al Mubaraki, M. and Busler, M. (2011). "The development of entrepreneurial companies through business incubator programs", International Journal of Emerging Sciences, vol. 1, no. 2, 2011, pp. 95.

[3] Audretsch, D. B. and Keilbach, M. (2004). "Entrepreneurship and regional growth: an evolutionary interpretation", Journal of evolutionary economics, vol. 14, no. 5, 2004, pp. 605-616.

[4] Audretsch, D. B. and Lehmann, E. E. (2005). "Does the knowledge spillover theory of entrepreneurship hold for regions?", Research policy, vol. 34, no. 8, 2005, pp. 1191-1202.

[5] Baldini, N. (2010). "University spin-offs and their environment", Technology Analysis \& Strategic Management, vol. 22, no. 8, 2010, pp. 859-876.

[6] Benneworth, P. and Charles, D. (2005). "University spin-off policies and economic development in less successful regions: learning from two decades of policy practice”, European Planning Studies, vol. 13, no. 4, 2005, pp. 537557.

[7] Colombo, M. G. and Piva, E. (2005). "Are academic start-ups different? A matched pair analysis", 32th Annual EARIE Conference, Oporto, 2005, pp. 129.

[8] Di Gregorio, D. and Shane, S. (2003). "Why do some universities generate more start-ups than others?", Research policy, vol. 32, no. 2, 2003, pp. 209227.

[9] Djokovic, D. and Souitaris, V. (2008). "Spinouts from academic institutions: a literature review with suggestions for further research", The journal of technology transfer, vol. 33, no. 3, 2008, pp. 225-247. 
[10] Fini, R., Grimaldi, R., Santoni, S. and Sobrero, M. (2011). "Complements or substitutes? The role of universities and local context in supporting the creation of academic spin-offs", Research Policy, vol. 40, no. 8, 2011, pp. 1113-1127.

[11] Fini, R., Perkmann, M. and Michael Ross, J. (2021). "Attention to exploration: The effect of academic entrepreneurship on the production of scientific knowledge", Organization Science, 2021.

[12] Gilbert, B. A., McDougall, P.P. and Audretsch, D. B. (2008). "Clusters, knowledge spillovers and new venture performance: An empirical examination", Journal of business venturing, vol. 23, no. 4, 2008, pp. 405-422.

[13] Kolympiris, C., Kalaitzandonakes, N. and Miller, D. (2014). "Public funds and local biotechnology firm creation”, Research Policy, vol. 43, no. 1, 2014, pp. 121-137.

[14] Lockett, A. and Wright, M. (2005). "Resources, capabilities, risk capital and the creation of university spin-out companies", Research policy, vol. 34, no. 7, 2005, pp. 1043-1057.

[15] Lockett, A., Siegel, D., Wright, M. and Ensley, M. D. (2005). “The creation of spin-off firms at public research institutions: Managerial and policy implications", Research policy, vol. 34, no. 7, 2005, pp. 981-993.

[16] Ndonzuau, F. N., Pirnay, F. and Surlemont, B. (2002). "A stage model of academic spin-off creation", Technovation, vol. 22, no. 5, 2002, pp. 281-289.

[17] O'shea, R. P., Alle, T.J., Chevalier, A. and Roche, F. (2005). "Entrepreneurial orientation, technology transfer and spinoff performance of US universities", Research policy, vol. 34, no. 7, 2005, pp. 994-1009.

[18] O'Shea, R. P., Allen, T.J., Morse, K. P., O'Gorman, C. and Roche, F. (2007). "Delineating the anatomy of an entrepreneurial university: the Massachusetts Institute of Technology experience", R\&d Management, vol. 37, no. 1, 2007, pp. 1-16.

[19] O'Shea, R. P., Chugh, H. and Allen, T. J. (2008). "Determinants and consequences of university spinoff activity: a conceptual framework", The Journal of Technology Transfer, vol. 33, no. 6, 2008, pp. 653-666.

[20] Oakey, R. P. (2003). "Technical entreprenenurship in high technology small firms: some observations on the implications for management", Technovation, vol. 23, no. 8, 2003, pp. 679-688.

[21] Pazos, D. R., López, S. F., González, L. O. and Sandiás, A. R. (2012). “A resource-based view of university spin-off activity: New evidence from the Spanish case", Revista Europea de Dirección y Economía de la Empresa, vol. 21, no. 3, 2012, pp. 255-265.

[22] Perkmann, M., Tartari, V., McKelvey, M., Autio, E., Broström, A., D’este, P. and Sobrero, M. (2013). "Academic engagement and commercialisation: A review of the literature on university-industry relations", Research policy, vol. 42, no. 2, 2013, pp. 423-442.

[23] Powers, J. B. and McDougall, P. P. (2005). "University start-up formation and technology licensing with firms that go public: a resource-based view of 
academic entrepreneurship", Journal of business venturing, vol. 20, no. 3, 2005, pp. 291-311.

[24] Prokop, D., Huggins, R. and Bristow, G. (2019). "The survival of academic spinoff companies: An empirical study of key determinants", International Small Business Journal, vol. 37, no. 5, 2019, pp. 502-535.

[25] Rasmussen, E. and Borch, O. J. (2010). "University capabilities in facilitating entrepreneurship: A longitudinal study of spin-off ventures at mid-range universities", Research policy, vol. 39, no. 5, 2010, pp. 602-612.

[26] Rasmussen, E., Mosey, S. and Wright, M. (2014). "The influence of university departments on the evolution of entrepreneurial competencies in spin-off ventures", Research policy, vol. 43, no. 1, 2014, pp. 92-106.

[27] Sciarelli, M., Landi, G. C., Turriziani, L. and Tani, M. (2021). "Academic entrepreneurship: founding and governance determinants in university spin-off ventures", The Journal of Technology Transfer, vol. 46, no. 4, 2021, pp. 10831107.

[28] Shane, S. A. (2004). "Academic entrepreneurship: University spinoffs and wealth creation", Edward Elgar Publishing, 2004.

[29] Smith, H. L., Chapman, D., Wood, P., Barnes, T. and Romeo, S. (2014). "Entrepreneurial academics and regional innovation systems: the case of spinoffs from London's universities", Environment and Planning C: Government and Policy, vol. 32, no. 2, 2014, pp. 341-359.

[30] Sorenson, O. and Audia, P. G. (2000). "The social structure of entrepreneurial activity: Geographic concentration of footwear production in the United States, 1940-1989", American Journal of Sociology, vol. 106, no. 2, 2000, pp. 424462.

[31] Sternberg, R. (2014). "Success factors of university-spin-offs: Regional government support programs versus regional environment", Technovation, vol. 34, no. 3, 2014, pp. 137-148.

[32] Tödtling, F., Lengauer, L. and Höglinger, C. (2011). "Knowledge sourcing and innovation in "thick" and "thin" regional innovation systems - comparing ICT Firms in two Austrian regions", European Planning Studies, vol. 19, no. 7, 2011, pp. 1245-1276.

[33] Van Looy, B., Landoni, P., Callaert, J., Van Pottelsberghe, B., Sapsalis, E. and Debackere, K. (2011). "Entrepreneurial effectiveness of European universities: An empirical assessment of antecedents and trade-offs", Research policy, vol. 40, no. 4, 2011, pp. 553-564.

[34] Vinig, T. and van Rijsbergen, P. (2010). "University technology transfer: comparative study of US, European and Australian universities", Handbook of research on high-technology entrepreneurs, vol. 179, 2010. 